\title{
AGROECOLOGICAL ASSESSMENT OF GREEN MANURES GROWN FROM WINTER GRAIN HARVEST LOST IN THE CONDITIONS OF THE RIGHT-BANK FOREST-STEPPE OF UKRAINE
}

\author{
Razanov Serhiy $^{1 *}$, Ovcharuk Vitaliy ${ }^{2}$, Krasnyak Olena $^{3}$, Bakhmat Mykola ${ }^{4}$, Bakhmat Oleg $^{5}$ \\ ${ }^{1 * 2,3}$ Vinnytsia National Agrarian University, 3, Soniachna Str., 21008, Vinnytsia, Ukraine; \\ ${ }^{4,5}$ State Agrarian and Engineering University, 13, Shevchenko Str., 32316, Kamianets-Podilskyi, Ukraine; \\ *Corresponding Author Razanov Serhiy, e-mail: razanovsergej65@gmail.com;
}

Received July 2021; Accepted August 2021; Published September 2021;

DOI: $\underline{\text { https://doi.org/10.31407/ijees11.429 }}$

\begin{abstract}
To increase soil fertility and reduce their pollution by various harmful substances, including heavy metals, to replace chemical fertilizers, which are a source of these toxicants the main task for nowdays. The content of nitrogen, macro- and microelements in the vegetative mass grown from lost (from 5\% to 8\%) grain during the harvest of winter wheat, winter barley, winter rape and winter peas was studied. It was found that the yield of vegetative mass grown from grain lost during harvesting is $4500 \mathrm{~kg} \mathrm{ha}^{-1}$ - winter wheat, $3700 \mathrm{~kg} \mathrm{ha}^{-1}$ - winter barley, $11500 \mathrm{~kg} \mathrm{ha}^{-1}$ - winter rape and $6200 \mathrm{~kg} \mathrm{ha}^{-1}$ - winter peas. The concentration of phosphorus, potassium, calcium, magnesium and sodium in the vegetative mass of these greens was respectively in the range of $0.65 \mathrm{~g} \mathrm{~kg}^{-1}-1.25 \mathrm{~g} \mathrm{~kg}^{-1} ; 3.1 \mathrm{~g} \mathrm{~kg}^{-1}-$ $4.8 \mathrm{~g} \mathrm{~kg}^{-1} ; 1.01 \mathrm{~g} \mathrm{~kg}^{-1}-3.1 \mathrm{~g} \mathrm{~kg}^{-1} ; 0.21 \mathrm{~g} \mathrm{~kg}^{-1}-0.75 \mathrm{~g} \mathrm{~kg}^{-1}$; and $0.18 \mathrm{~g} \mathrm{~kg}^{-1}-0.52 \mathrm{~g} \mathrm{~kg}^{-1}$. While the concentration of lead, cadmium, copper, zinc, manganese and cobalt in the vegetative mass of green manures grown from grain harvested during the harvest of winter wheat, winter barley, winter rape and winter peas was $0.02 \mathrm{mg} \mathrm{kg}^{-1}-0.024$

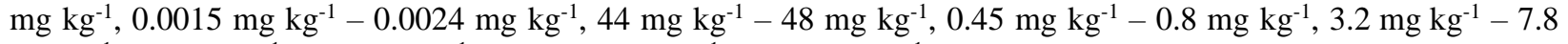
$\mathrm{mg} \mathrm{kg}{ }^{-1}, 4.3 \mathrm{mg} \mathrm{kg}^{-1}-7.3 \mathrm{mg} \mathrm{kg}^{-1}$ and $0.017 \mathrm{mg} \mathrm{kg}^{-1}-0.22 \mathrm{mg} \mathrm{kg}^{-1}$. The nitrogen content in the vegetative mass of green manures obtained from 1 ha ranged from 21600 to $52100 \mathrm{~g}$. The use of these green manures in crop production has a higher environmental efficiency of fertilizers due to low concentrations of lead, cadmium, zinc and copper compared to mineral fertilizers. The coefficient of accumulation in the vegetative mass of green manures was from 0.016 to 0.019 for lead, from 0.0053 to 0.0085 for cadmium, from 0.2 to 0.27 for zinc and from 0.59 to 0.78 for manganese.
\end{abstract}

Key words: Green manure, Winter wheat, Winter barley, Winter rape, Winter peas, Yield, Nitrogen, Macronutrients, Microelements, Grain. 